\title{
Scarlet fever associated with hepatitis in pediatrics. A case report
}

\section{Hepatitis asociada a escarlatina en pediatría. Reporte de caso}

\author{
Arvind V. Panchoo ${ }^{\mathrm{a}}$, Miguel Saps ${ }^{\mathrm{b}}$, Edgardo D. Rivera Rivera ${ }^{\mathrm{b}}$
}

aDepartment of Pediatrics, Jackson Memorial Hospital

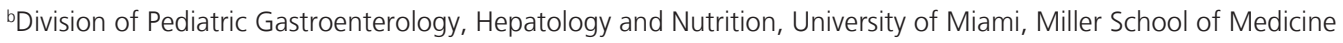

Recibido el 4 de abril de 2018; aceptado el 25 de mayo de 2018

\section{Keywords:}

Scarlet Fever; hepatitis; group A beta-hemolytic streptococcus; pediatrics 


\section{Introduction}

Scarlet Fever is a common pediatric illness caused by group A beta hemolytic Streptococcus (GABHS), usually following an episode of pharyngitis ${ }^{1,2}$. Typically, it is characterized by fever, a red colored tongue and fine erythematous rash followed by desquamation $^{1,3}$. Rheumatic fever, glomerulonephritis, septic arthritis, osteomyelitis, pneumonia and otitis media are some of the well-documented complications of GABHS infection ${ }^{1,2}$. Nevertheless, with appropriate antibiotic treatment scarlet fever carries an overall excellent prognosis. Hepatitis secondary to scarlet fever is a rare complication described in adults and even less frequently in children ${ }^{2}$. Though the association between scarlet fever and hepatitis was first reported in 1931, the pathogenesis still remains largely unknown, and there exist only few pediatrics cases in the literature highlighting the course, prognosis and eventual outcomes of these patients ${ }^{1-6}$. Herein, we report a pediatric case of scarlet fever associated with hepatitis, the first to the best of our knowledge in over fifty years in North America. The objective of this article is to raise awareness among pediatricians regarding possible hepatic involvement with scarlet fever.

\section{Clinical case}

A 12 year old male with recently diagnosed scarlet fever presented to our institution with a four day history of jaundice, dark urine and decreased appetite. His illness began nine days prior to admission with fever and sore throat. On the third day he developed an erythematous, papular rash of the face, trunk and extremities. He was taken to an urgent care center where a rapid antigen test (throat swab) for group A Streptococcus was found to be positive. Subsequently, the patient was diagnosed with scarlet fever and started on a five day course of amoxicillin.

In our emergency department, his vital signs were all stable and normal for age. Physical examination revealed bilateral scleral icterus, fine, erythematous, papular rash over the face, trunk and extremities without abdominal tenderness, hepatomegaly or splenomegaly. Initial laboratory evaluation was significant for hemoglobin of $11.8 \mathrm{~g} / \mathrm{dl}$ [Reference Range 11-16g/ $\mathrm{dl}$ ], elevated white blood cells of 20,300/ml [Reference Range 4,500-13,000/ml] with a neutrophil predominance, normal electrolyte and renal function profile, elevated anti-streptolysine O (ASO) titer of $209 \mathrm{IU} / \mathrm{ml}$ [Reference Range $<200 \mathrm{IU} / \mathrm{ml}$ ], elevated liver enzymes and elevated total and direct bilirubin levels (Table 1). Urinalysis was positive for bilirubinuria without proteinuria, hematuria or pyuria. Ultrasound examination of the liver, gallbladder and biliary system was unremarkable, with the spleen demonstrating normal echogenicity and size.

At that point the Pediatric Gastroenterology service was consulted and further investigations were performed. These included antibody serology tests for hepatitis viruses A, B and C, hepatitis B surface antigen, antinuclear antibody, DNA polymerase chain reaction (PCR) for Epstein Barr virus, parvovirus B19, adenovirus, cytomegalovirus, human herpes virus 6 , herpes simplex virus 1 and herpes simplex virus 2 . All of these resulted negative. Serum ceroplasmin and $\mathrm{C} 3$ and $\mathrm{C} 4$ complement levels were also sought and were found to be in the normal range.

The patient was provided with symptomatic care and by day eleven of illness his rash began to fade, and desquamation of the palms and soles was observed. He was discharged with good oral tolerance following a stable hospital course. At outpatient follow up three weeks later, he was asymptomatic with resolution of icterus and down trending liver enzymes (Table 1).

Table 1. Laboratory Parameters with Reference Ranges in Parenthesizes

\begin{tabular}{|c|c|c|c|c|c|c|}
\hline Laboratory parameter & $\begin{array}{l}\text { Day } 1 \text { of } \\
\text { admission }\end{array}$ & $\begin{array}{l}\text { Day } 2 \text { of } \\
\text { admission }\end{array}$ & $\begin{array}{c}\text { Day } 3 \text { of } \\
\text { admission }\end{array}$ & $\begin{array}{l}\text { Day } 4 \text { of } \\
\text { admission }\end{array}$ & $\begin{array}{l}\text { Day } 5 \text { of } \\
\text { admission }\end{array}$ & $\begin{array}{l}\text { Outpatient } \\
\text { Visit }\end{array}$ \\
\hline AST (15-46 units/L) & 151 & 189 & 177 & 249 & 267 & 70 \\
\hline ALT (21-72 units/L) & 256 & 273 & 273 & 297 & 293 & 79 \\
\hline A LP (114-501 units/L) & 361 & 415 & 471 & 510 & 514 & 498 \\
\hline GGTP (3-18 units/L) & 649 & & 862 & 934 & 867 & \\
\hline Total Bilirubin $(0.2-1.3 \mathrm{mg} / \mathrm{dl})$ & 5.8 & 5.7 & 5.6 & 4.4 & 4.0 & 1.0 \\
\hline Direct Bilirubin (0-0.4 mg/dl) & 5.0 & 4.8 & 4.6 & 3.7 & 3.3 & \\
\hline
\end{tabular}

$\mathrm{AST}=$ aspartate aminotransferase; $\mathrm{ALT}=$ alanine aminotransferase; $\mathrm{ALP}=$ alkaline phosphatase; $\mathrm{GGTP}=$ gamma-glutamyl transpeptidase 


\section{Discussion}

The incidence of hepatitis with scarlet fever in pediatrics is not known, but by all accounts seems to be rare. Contributing to this uncertainty are published cases of hepatitis in scarlet fever without jaundice, leading some authors to believe that hepatitis may simply be missed or overlooked in scarlet fever without icterus $^{3,5}$.

Girisch and Heinger on review of the literature noted that hepatitis appears to closely follow the development of the characteristic rash ${ }^{5}$. As in our case, the patient developed a fine erythematous, papular facial rash on day three of illness and then experienced onset of jaundice and dark urine on the sixth day, with elevations of liver enzymes discovered soon after.

Though first described by MacMahon and Mallory in 1931, the pathogenesis of liver involvement in scarlet fever remains unclear ${ }^{4}$. In an autopsy series of fifty-nine cases of scarlet fever, post-mortem cultures of lung tissue and blood yielded growth of GABHS but those from liver tissue did not; arguing against direct bacterial hepatic injury ${ }^{1}$. However, streptococcal pyrogenic exotoxin mediated cellular injury has been proposed as a possible mechanism of hepatoxicity in GABHS infections. It is believed that such exotoxins have the ability to interact with both the major histocompatibility complex molecules of antigen presenting cells and T-cell receptors, thereby acting as 'super antigens', with the end result of stimulating $\mathrm{T}$ cells to produce cytokines capable of inciting liver injury ${ }^{7}$.

It has been demonstrated that individuals produce varying degrees of cytokine responses to the same streptococcal super antigen. In that study, the investigators noted that patients with a propensity to produce higher levels of cytokines experienced more significant systemic manifestations than those who produce lower levels of cytokines in response to the same streptococcal super antigen ${ }^{8}$. Indeed, in preparing this report we came across two cases of hepatitis in scarlet fever associated with gallbladder hydrops; one even describing splenomegaly and ascites ${ }^{3,9}$. All of this is to say, that there may exist, a spectrum of scarlet fever disease presentation, possibly attributed to host factors affecting the level of lymphokine production in response to GABHS infection, with scarlet fever associated hepatitis being on the more severe end of the range.

Patients presenting with a clinical picture of cholestatic hepatitis in the setting of scarlet fever raises a number of etiological considerations. Leptospirosis for instance shares many similar features seen in our patient, namely; jaundice, fever, neutrophilic leukocytosis and even various skin exanthemas has been observed in this disease process ${ }^{10}$. The absence of sig- nificant abdominal tenderness, hepatomegaly, splenomegaly, myalgia, headache, renal involvement and history of exposure to infected animals (dogs, rodents) makes this condition less likely. Bradycardia and high remittent fever have been described in association with leptospirosis ${ }^{10}$, none of which occurred during our patient's disease course.

Many of the clinical features observed in this case can be attributed to Kawasaki disease and typhoid fever. Our patient described a four day history of intermittent fever and never exhibited mucous membrane changes, bilateral conjunctival injection or cervical lymphadenopathy, hence his presentation did not meet the diagnostic criteria for complete Kawasaki disease $^{11}$. Kawasaki disease can be associated with mild to moderate elevations of serum transaminases and hyperbilirubinemia but without objective evidence of at least five days of fever and other supplemental laboratory criteria such as pyruia and thrombocytosis (platelet count $>500 \times 10^{3} / \mathrm{microL}$ ), incomplete Kawasaki disease remains very unlikely ${ }^{12}$. Typhoid fever was essentially ruled out given the lack of characteristic salmon-colored spots on trunk and abdomen, bradycardia or travel to areas where this illness is endemic ${ }^{3}$.

Since our patient presented with cholestatic hepatitis and received amoxicillin, some readers may question whether this may have been secondary to amoxicillin use. Hepatitis is a very rare occurrence with amoxicillin treatment, having a six fold higher incidence when a combination of amoxicillin and clavunate is used. Also, such reports describe older patients with longer durations of antibiotic use ${ }^{13}$. Our patient was prescribed a five day course of only amoxicillin.

Scarlet fever is diagnosed largely on clinical manifestations but in equivocal cases pharyngeal culture and ASO titers are followed ${ }^{14}$. ASO titers begin to rise after 1 week of illness and peaks in three to five wee$\mathrm{ks}^{3}$. Given a history of fever, sore throat, characteristic rash with desquamation, a positive rapid antigen test for group A Streptococcus and elevated ASO titers the authors feel confident that this patient's cholestatic hepatitis is associated with an initial presentation of scarlet fever.

At outpatient follow up, liver enzymes were noted to have decreased significantly, though still mildly elevated from normal. Unfortunately the patient has defaulted from outpatient visits but has expressed to clinical staff the absence of jaundice, dark urine, pale stools and abdominal pain in a telephone interview four months post hospital discharge.

To the best of our knowledge, this report presents the first case of scarlet fever associated with hepatitis in over fifty years in North America. The last, described 
an 18 year old female admitted to a University Hospital in Maryland in 1962. Scarlet fever was diagnosed based on typical clinical symptoms and positive pharyngeal culture, with hepatitis noted on liver biopsy ${ }^{10}$. Since then other cases have been sporadically identified in various nationalities ${ }^{1-6,9,15,16}$.

\section{Conclusion}

Many healthcare providers, including general pediatricians may not be aware of this entity, potentially leading to thorough investigation and a more prolonged hospital course that can significantly increase the cost of health care. With this case we aim to raise awareness among pediatricians regarding possible hepatic involvement with scarlet fever and underline that such patients generally follow a benign disease course with complete recovery expected over several weeks to months.

\section{Responsabilidades Éticas}

Protección de personas y animales: Los autores declaran que los procedimientos seguidos se conformaron a las normas éticas del comité de experimentación humana responsable y de acuerdo con la Asociación Médica Mundial y la Declaración de Helsinki.

Confidencialidad de los datos: Los autores declaran que han seguido los protocolos de su centro de trabajo sobre la publicación de datos de pacientes.

Derecho a la privacidad y consentimiento informado: Los autores han obtenido el consentimiento informado de los pacientes y/o sujetos referidos en el artículo. Este documento obra en poder del autor de correspondencia.

\section{Conflicto de intereses}

Los autores declaran no tener conflicto de intereses.

\section{References}

1. Elishkewitz K, Shapiro R, Amir J, Nussinovitch M. Hepatitis in Scarlet Fever. IMAJ. 2004;6:569-70.

2. Gidaris D, Zafeiriou D, Mavridis P, Gombakis N. Scarlet Fever and Hepatitis: a case report. Hippokratia. 2008;12:186-7.

3. Wang LY, Young TH. Hepatitis, Gallbladder Hydrops, Splenomegaly, and Ascites in a Child With Scarlet Fever. PediatrEmer Care. 2012;28:1215-7.

4. Kocak N, Ozsoylu S, Ertugrul M, Ozdol G. Liver Damage in Scarlet Fever. Clinical Pediatrics. 1976;15:462-4.

5. Girisch M, Heininger U. Scarlet Fever Associated with Hepatitis- A report of Two cases. Infection. 2000;28:251-3.

6. Guven, A. Hepatitis and Hematuria in Scarlet Fever. Indian J Pediatr 2002;69:985-6.
7. Stevens DL. Streptococcal toxic shock syndrome: spectrum of disease, pathogenesis, and new concepts in treatment. Emerg Infect Dis. 1995;1:69-78.

8. Norrby-Teglund A, Chatellier S, Low DE, McGeer A, Green K, Kotb M. Host variation in cytokine responses to superantigens determine the severity of invasive group A streptococcal infection. Eur. J. Immunol. 2000;30:3247-55.

9. Rocco R, Benedetti L, Escudero G, Jordan F. Hydrops of the gallbladder and hepatitis associated with scarlet fever. ActaGastroenterolLatinoam. 2010;40:61-

10. Fishbein WN. Jaundice as an Early Manifestation of Scarlet Fever. Ann Intern Med.1962;57:60-72.

11. Son MBF, Newburger JW. Kawasaki Disease. Pediatrics in Review.2018; 39(2):78-90.
12. Fimbres AM, Shulman ST. Kawasaki Disease. Pediatrics in Review.2018; 29(9):308-16.

13. Lucena MI, Andrade RJ, Fernández $\mathrm{MC}$, et al. Determinants of the clinical expression of amoxicillin-clavulanate hepatotoxicity: a prospective series from Spain. Hepatology. 2006; 44:850-6.

14. Basetti S, Hodgson J, Rawson TM, Majeed A. Scarlet fever: a guide for general practitioners. London Journal of Primary Care. 2017; 9:5, 77-9, DOI: 10.1080/17571472.2017.1365677.

15. Gutierrez Junquera C, Escudero Canto MC, Ruiz Cano R, Cu arterodelPozo I, Gil Pons E. Cholestatichepatitis as initialmanifestationofscarletfever. AnPediatr. 2003; 59:193-4.

16. Gomez-Carrasco JA, Lassaletta A, Ruano D. Acute hepatitis may form part of scarlet fever. AnPediatr. 2004; 60: 382-3. 